\title{
Peer Response in ESL Writing
}

\section{Gloria M. Tang and Joan Tithecott}

This article explores the value of peer response groups in English as a second language (ESL) writing classes. It reports on some of the findings of a study (Tithecott, 1997) conducted in a small university college in Western Canada with 12 international students from Asia to investigate: (a) what the perceptions of students were with regard to peer response and whether their perceptions changed over time; (b) what kind of activities students engaged in during peer response sessions; and (c) whether and how students changed their writing as a result of participating in response sessions. Research methodology included examining and analyzing student journal entries, audiotapes of peer response sessions, and the drafts and final versions of student writing. Results show that Asian ESL students tended to be positive about peer response and that they became somewhat more positive as the semester progressed. Although they appreciated the benefits of peer response, they had some concerns about peer feedback. Some students revised their writing using peer comments. During the peer response sessions students engaged in a variety of social, cognitive, and linguistic activities as they worked to accomplish the assigned task.

\section{Background to the Study}

The enrollment of ESL students in postsecondary institutions in North America, including small university colleges away from major urban centers, is steadily increasing. In the university college in Western Canada in which this peer response study was conducted, for example, the number of students has increased fourfold in the past decade. Many international students, mainly from Asia, come to North America to complete certificate, diploma, and degree programs. Because of high tuition fees and living expenses, they find themselves under considerable pressure to finish their education as quickly as possible. However, their facility with English for academic purposes varies from student to student, and some individuals need additional language instruction and support before they are able to enroll in mainstream courses and programs. Typically, these students are placed in ESL classes to improve their English. In an attempt to introduce approaches and classroom activities that promote language learning, writing instructors employ many different approaches and techniques. One such technique is the use of peer response groups in the writing classroom. 


\section{Why Peer Response Groups?}

Peer response groups stand at the center of a fortuitous convergence of theories of language development and theories of language learning and teaching in second language (L2) classrooms. First, the use of such groups has increased with the shift to the process approach to writing (Flower \& Hayes, 1981) and the consequent emphasis on helping students to acquire strategies "for getting started ... for drafting ... for revising ... and for editing" (Silva, 1990, p. 15). The process approach to writing has at its heart evaluation (Hilgers, 1986; Samway, 1993). When writers reread and change text, they evaluate their work. Peer response groups provide an opportunity for peers to develop criteria for evaluation and to practice evaluating their own written text and that of others.

Second, in the communicative language classroom the focus is on student-centered learning as opposed to the more traditional teacher-fronted class (Savignon, 1991). Peer response groups allow the writing instructor to move toward an equitable balance between teacher-centered instruction and student-centered activities.

Third, when correctly structured, peer response groups provide increased opportunities not only for comprehensible input (Krashen, 1982) but also for comprehensible output (Swain, 1985) and for "negotiated interaction" (Gass \& Selinker, 1994, p. 217), which are considered crucial factors in L2 acquisition. Negotiation requires attentiveness and involvement, both of which are necessary for successful communication.

Fourth, peer response groups are a form of cooperative language learning, the benefits of which are well researched (McGroarty, 1989). These benefits include academic achievement and language development as well as improved social relations and increased self-confidence (Coelho, 1992; Slavin, 1991), to name a few.

Finally, theories of learning maintain that learning comes about as a result of social interaction (Vygotsky, 1986); peer response groups afford an opportunity for such interaction. Members of a group, through conversation, help each other generate ideas; support and encourage each other during the composing process; and provide an increased sense of audience for each other (Urzua, 1987). Through interaction, writers become aware of the reader for whom the text is composed. Writing thus becomes the focus of conversation for a community of peers in the classroom. Properly structured, peer response groups create opportunities for scaffolding. For the purpose of this article, scaffolding is defined as the assistance provided by a teacher/adult or a more capable peer to the child or less capable peer so that the two together are able to accomplish the task they have been set (Cazden, 1988).

In short, the use of peer response groups is supported by general theories of language learning, principles of cooperative learning, the cognitive process theory of writing, and theories of second language acquisition. 


\section{Literature Review}

Research in peer response has focused on a number of aspects, among them (a) the kind of interaction that takes place during the activity; (b) the revision of the writing as a result of the interaction; and (c) the perceptions of students toward the activity.

\section{Peer Interaction}

Recently researchers have begun to study what actually occurs during peer response sessions. Mendonça and Johnson (1994) studied 12 advanced nonnative speakers of English in order to explore the types and frequencies of peer negotiation that took place during peer response sessions. The researchers categorized five types of negotiation and calculated the frequency of each type. They concluded that the advanced ESL students they studied were able to focus on local and global discourse issues; and that peers became "aware of how their writing affected readers ... and could share knowledge about written texts" (p. 756). They also discovered that "reviewers tended to initiate all types of negotiations except explanations of content" (p. 756). In another study of a homogeneous group of 54 ESL students, Villamil and De Guerrero (1996) took a comprehensive look at what actually took place when $\mathrm{L} 2$ learners participated in a joint revision and how they helped each other. The authors identified a number of sociocognitive activities, for example, reading, evaluating, pointing to trouble sources, writing comments, and discussing task procedures, as well as substrategies for providing scaffolding that students employed in peer response sessions either during peer interaction or during the revision process. These substrategies include instructing, announcing, justifying, restating, giving directives, requesting clarification, clarifying, eliciting, responding to elicitation and reacting (Villamil \& De Guerrero, 1996). Although these findings are enlightening, the participants in Villamil and De Guerrero's (1996) study were carefully selected. Further research is thus needed to determine if other groups of ESL students interact in similar ways during peer response sessions. The present study attempted to find out whether the types of peer response negotiations noted by Villamil and De Guerrero (1996) could be found in a group of ESL students who were heterogeneous in background, language proficiency, and education when they engaged in similar tasks.

\section{Impact on Revision}

Results of Hedgcock and Lefkowitz's (1992) study conducted in an English as a foreign language context show that the students who participated in peer feedback performed as well as those who received teachers' feedback; that teacher feedback resulted in improvement in grammar whereas peer feedback resulted in revisions made to content, organization, and vocabulary; and that although the procedure did not produce significantly im- 
proved L2 composition, "the data suggested that the technique [did] not result in grammatically inferior writing" (p. 264) on the part of the peer response group members. These results support the results of an earlier study by Fathman and Whalley (1990). Hedgcock and Lefkowitz (1992) conclude that peer evaluation can result in satisfactory revising behavior. Prompted by these promising results, we designed this study to discover whether an oral feedback format would produce similar results to those of Hedgcock and Lefkowitz's (1992) study in which written feedback was used.

Studies on whether students use peer comments to revise their writing have mixed results. Mendonça and Johnson (1994) concluded that in 53\% of the instances of revision, students incorporated their peers' comments. In Connor and Asenavage's (1994) study, however, only " $5 \%$ of the revision resulted from peer comments, [whereas] $35 \%$ could be described as resulting from teacher comments and $60 \%$... as a result of self/others" (p. 264). These mixed results call for further study, and the present study sought to explore the revising behaviors of a heterogeneous group of ESL students participating in peer response sessions.

\section{Preferences for Types of Feedback}

With regard to students' preference of feedback, Saito's (1994) study of three classes of university students indicated that students tend to favor teacher feedback over peer feedback or self-correction. However, in one of the classes that was composed of advanced students enrolled in a credit course, $80 \%$ of the responses indicated peer feedback as useful. In Zhang's (1995) study investigating the affective advantage of peer feedback with L2 classes, results showed that nearly $94 \%$ of the participants indicated preference for the traditional feedback over nonteacher feedback. These concerns were considered when the present study was conducted.

\section{Students' Perceptions}

The findings of research on the perceptions of students and their reasons for those perceptions indicate that for most students, peer review is perceived as a beneficial technique (Mangelsdorf, 1992; Obah, 1993). Students are appreciative of the social contact, the opportunity to speak English and share ideas, and the chance to learn from others. Negative views focus on the limitations of the student reviewer and the task itself (Mangelsdorf); and the feeling of inadequacy on the part of the reviewer (Obah). It is interesting that "almost all of the students with totally negative views [come] from cultures that stress teacher-centered classrooms" (p. 280). These results are of particular interest to the present study as the students of this study are all of Asian backgrounds.

The present study was prompted by real concerns on the part of the instructor to discover effective classroom techniques for her students, to find 
out whether her Asian ESL students at the college level had negative views of peer response sessions, and to determine whether they would benefit from peer response groups as students seemed to have in many studies (Mangelsdorf, 1992; Mittan, 1989; Obah, 1993). More specifically, the study was conducted to investigate (a) what the perceptions of students were with regard to peer response and whether their perceptions changed over time; (b) what kind of activities and strategies students engaged in during response sessions; and (c) whether and how students changed their writing as a result of participating in response sessions.

\section{The Study}

This study was undertaken in a small university college in the interior of British Columbia between January and April 1997. Students were recruited from various countries, including Korea, Japan, Taiwan, and others. The College English as a Second Language (CESL) program has grown steadily, and at the time of the study there were approximately 400 ESL students and 20 instructors.

\section{The Participants}

The 12 participants in the study were a heterogeneous group of students in a Level 4 class, that is, upper intermediate to lower advanced with an average TOEFL score of 500-540. There were two men and 10 women from different Asian countries: Japan (7), Korea (2), Hong Kong (1) Taiwan (1), and India (1). Their backgrounds, L2 proficiency, and interests varied considerably. Some were in Canada to learn English for two years before returning to their home country, whereas others were preparing for academic work in certificate, diploma, or degree programs in North America. Some had finished degree programs, whereas many had completed two years of junior college in their home countries.

\section{The Peer Response Model}

For this study the instructor used as a model a video entitled Student Writing Groups: Demonstrating the Process (1988). The video is based on a model described in Writing Without Teachers (Elbow, 1973). The peer response group in the video consists of four members. The process is summarized in Table 1. To begin with, the first group member reads his or her essay through from beginning to end while the others listen attentively. During the first reading no one in the group takes notes. Once the first reading is completed, those who have been listening take a few minutes to write one or two sentences stating their general impression of the essay as they have understood it. At this point, if the reader/author has noticed anything in his or her text that might need to be changed, he or she jots it down. Then the same essay is read a second time. During this reading the other three group members write 
Table 1

The Peer Response Model

\begin{tabular}{lll}
\hline Step & Author's activities & Peers' activities \\
\hline 1 & Reads essay aloud & Listen attentively-no writing \\
2 & Self corrects if any & Write down general impression of essay \\
3 & Reads essay aloud again & Listen and write down specific responses to essay \\
4 & Listens to and & Peer 1 reports \\
& takes down notes of & Peer 2 reports \\
& peer feedback & Peer 3 reports \\
\hline
\end{tabular}

down their responses. It is helpful if students note key words under three columns: features they like, things that do not work for them, and areas of confusion.

After the second reading the group members comment orally on the essay referring to the notes they have taken. The author/reader listens to and writes down all comments, positive as well as negative. Later, when the author revises the text, decisions can be made regarding which comments to act on and which comments to set aside. In this model it is important that during the oral feedback part of the process the author not converse with the other group members. Once all three listeners have reported orally to the author, it is then the next student's turn to present his or her writing for response.

This model was chosen by the instructor for its oral component. She wanted the students to hear their own writing (DiPardo \& Freedman, 1988). The value of reading their own writing aloud can be linked to Vygotsky's (1986) views of speech, which he defines as a "self-monitoring, or thinking aloud which is intermediate between public utterances and inner speech" (p. 94). In addition to the benefits of students hearing their work, oral/aural interaction during peer response sessions is also a more efficient means of providing feedback in terms of the amount of time used. Besides, it served the instructor's purpose of directing students' attention to more global matters of content and organization with attention to form delayed until the editing of the final draft. Moreover, the peer response group as structured in the model is a social institution bringing together language (peer talk), thought (writing made public), and action (revising) to make it possible for the group members to create new levels of thinking. Another benefit of this model is that speaking about writing gives students further opportunities for practice in the target language for negotiating meaning. Mangelsdorf (1989) 
maintains, "the voices that speak in the classroom can empower the voices struggling to be heard in the papers" (p. 134).

\section{Conduct of the Study}

Students were briefed on the study and the procedure of the study. The briefing was followed by a training session in which students discussed suitable language to use in their comments, particularly about features that were puzzling or problematic in group members' writing. They came up with phrases such as, "I was wondering," "That doesn't work for me," "I think," "I'm confused about," "I don't understand what you mean by," and "I was worried about." Students were cautioned against using the modals that express prohibition: cannot, may not, should not (Leech \& Svartvik, 1975).

Then they wrote the first draft of an essay on a given topic to read aloud to a small group in class at an assigned time. The prompt for the first essay follows.

At certain times in our lives we come under the influence of a person who affects us in important and beneficial ways. Write an essay of 400500 words in which you identify such a person in your own life. Explain how that person came to influence your life. Give a clear and detailed illustration of a specific change or specific changes that resulted because of that person's influence on you. (Gregg, 1993, pp. 26-27)

The first peer response session and all other subsequent sessions followed the same pattern (see Table 1): authors read their essays aloud while their peers listened and took notes; peers gave oral feedback while authors were not allowed to defend or argue, only listen and take notes. Throughout the study, the instructor's role was one of facilitator and monitor. She allowed as much student autonomy (e.g., choosing their own initial group members) as possible. However, she was there to monitor the process; for example, she reminded students to take a moment after the first reading to jot down notes, monitored the language students used when giving feedback, answered questions, and gave encouragement to students.

After each peer response session, the instructor requested a journal entry in which the students were to describe their thoughts on the experience of taking part in the session. The instructor collected the journals, responded to them, and made a photocopy of each entry for data analysis. The journal entry was an opportunity for the students to consider what they had learned and to articulate their views about the classroom activity in which they had participated. It was hoped that the journal entry would stimulate the kind of reflection described as metacognitive experience which can lead an individual to establish new goals, can affect a person's metacognitive knowledge base, and can activate cognitive strategies (Flavell, 1979). 
Group membership was fixed until mid-term, after which groups were reorganized according to the results of the mid-term mark. The purpose was to create maximally heterogeneous groups. The regrouping was effected by rank ordering the marks; assigning the student with the highest mark, the student with the lowest mark, and the two middle students to the first group; the second highest and second lowest and two students with marks in the middle of the rankings to the second group; and the rest to the third group (Olsen \& Kagan, 1992). The students stayed in their new groups until the end of the semester.

The students participated in four peer response sessions during the term. The last session was audiotaped.

\section{The Data}

The following documents formed the data of the study:

- the instructor's own journal in which she kept a record of her questions about the situation, her conversation with students, her reflections on her practice, her plans and her emotional journey through the study;

- student journals in which the students recounted their reactions to the process after each session;

- drafts, notes and final versions of student writing; only the fourth writing assignment was analyzed;

- the tapes of the fourth peer response session that were transcribed and analyzed.

\section{Data Analysis}

The students' attitude toward the peer response sessions was determined by reading three journal entries of each student holistically and rating the entries as positive, mixed, or negative (Mangelsdorf, 1992). The three entries chosen were the entry after the first session, the entry written about midterm, and the entry after the last session. The totals in each category were calculated and expressed as percentages.

In addition, the journals were again examined to discover the concerns of the students regarding peer response in terms of the way the sessions were structured and the peer feedback they received; students' perception of whether they had gained as a result of the sessions; and whether their perceptions changed over time.

The audiotapes were transcribed and examined to discover the kind of activities in which the students actually engaged during peer response sessions. The transcriptions were examined in the light of research conducted by Villamil and De Guerrero (1996) and reviewed for activities, strategies, and aspects of social behavior as defined by Villamil and De Guerrero, that is, sociocognitive activities, mediating strategies, and significant aspects of social behavior such as how they handled their interaction regarding the text. 
Finally, the effects of peer response on revision were determined by examining the tape of the audiotaped session and reading the drafts and final versions of student writing. Comparing the drafts and the final copies illumined how the suggestions had been employed, and examining the tapescript along with the final versions shed light on the suggestions that were ignored. The analysis of the data yielded the following findings that are more appropriately referred to as observations.

\section{Findings of the Study}

Observation 1. Students' perceptions of peer response sessions varied from student to student and changed over the course of the semester.

Results of the analysis of student journal entries (see Table 2) show that in the first journal, the largest percentage of students expressed positive attitudes toward peer response sessions (50\%). For the second journal, however, results were quite different. This time, by far the majority of journal entries were rated as mixed (63.7\%). Having had more experience with sharing writing with peers, students were apparently more cognizant of some of the problems associated with these peer response sessions as they were used in this context. Interestingly enough, however, this time only one student journal entry was deemed negative. By the end of the semester, the perceptions of the students had apparently changed again. They became more balanced between positive (44.4\%) and mixed (55.6\%) attitudes, with the larger percentage of student journals in the mixed category. There were few negative journal entries $(2,1$, and 0 respectively in the three journal sessions).

It is interesting that the student perceptions of the present study appear to be similar to those of participants in other studies. Mangelsdorf (1992) asked a heterogeneous group of 40 students to answer four questions about peer response in writing. A comparison of the perceptions of the first journal entries of the students in this study and the perceptions of the students in Mangelsdorf's study indicates that the students' perceptions of peer responses of the two groups of students are similar (Table 3).

The following examples illustrate how students' perceptions toward peer response changed over the course of the semester. Terumi's entries docu-

Table 2

Perceptions of Peer Responses

\begin{tabular}{llll}
\hline Journal & Positive & Mixed & Negative \\
\hline 1. $(n=12)$ & $6(50 \%)$ & $4(33.3 \%)$ & $2(16.7 \%)$ \\
2. $\quad(n=11)$ & $3(27.3 \%)$ & $7(63.7 \%)$ & $1(9 \%)$ \\
3. $(n=9)$ & $4(44.4 \%)$ & $5(55.6 \%)$ & $0(0 \%)$ \\
\hline
\end{tabular}


mented the modifications in her attitude toward peer response sessions (pseudonyms are used throughout to preserve anonymity). Initially, her comments were mixed. She noted, "Working as a group was very helpful to me because the other students told me my bad points or good points in my essay." However, she was also aware of the difficulty of having "to tell the other students [her] comments."

Her second entry was positive. Reporting the process of the peer response sessions and reiterating the comments made in the first journal, she wrote, "This way is effective for us to progress my writing skill because the listeners give us their opinions that I didn't notice at all and also I can add the good opinions to my essay."

Her third journal entry was again mixed. Her classmates, she wrote, "give me my good points so I can recognize how I can write essay in a good way." However, she went on to comment on the difficulty of listening to long passages of text and reflected that, perhaps, the peer response process "helps [her] in a listening way too."

More dramatic changes were evident in Yukiko's views of peer response. In Yukiko's first journal entry, all the comments were negative: she revealed her lack of confidence in her ability to write a good essay; her embarrassment at having to read aloud her work, a concern shared by many students; and the difficulty of giving feedback to her fellow students. In her second journal, rated mixed, she still voiced her nervousness about reading in front of the class, but she focused more on the helpful aspects of the process. She stated, "The reason why I think it's helpful are easy to find your weakness in my essay, good practice for speak out, and can develop my hearing skills." By the third entry, which was rated positive, Yukiko's enthusiasm for the peer response sessions was clearly evident. Her final comment reflects her changed attitude,

People in my group including me don't hesitate to say both positive and negative parts so we all can be encouraged and know what is wrong with our essays. I think I am, or we are all helping with our essays.

Table 3

Comparison of Perceptions of Peer Responses

\begin{tabular}{lccc}
\hline Study & Positive & Mixed & Negative \\
\hline $\begin{array}{l}\text { Present study (1997) } \\
(n=12)\end{array}$ & $6(50 \%)$ & $4(33.3 \%)$ & $2(16.7 \%)$ \\
$\begin{array}{l}\text { Mangelsdorf (1992) } \\
(n=40)\end{array}$ & $22(55 \%)$ & $12(30 \%)$ & $6(15 \%)$ \\
\hline
\end{tabular}


Although most students did not undergo as dramatic a change in perception as Yukiko, their perceptions did change, some from mixed to positive and back to mixed, some from negative to positive and then to mixed.

Observation 2. Students saw the benefits of the peer response model used in the study but had concerns as well.

The aspects that were perceived to be beneficial yet to cause concern were the oral/aural nature of the task and the sharing of essays. A number of the students felt that their listening and speaking skills improved as a result of the sessions and that they had learned to listen attentively. Yukiko noted, "My speaking and listening skills have improved." However, the main benefits of reading their own essays aloud as perceived by the students were that it helped them find mistakes on their own and that it helped their peers to recognize "something unnatural." One student stated, "While I read my essay carefully so that the listener can understand easily, I find some grammar mistakes or wrong sentences." This was echoed by another who remarked, "After finishing reading my essay, I could find lots of mistakes from it which I didn't realize before. It's good opportunity to find mistakes by myself."

Reading aloud clearly enabled the students to become aware of their grammar mistakes, areas of confusion or trouble sources, and deficiencies in their work, supporting findings of previous studies that students saw their text in a new way by reading it aloud (Hedgcock \& Lefkowitz, 1992; Zamel, 1983). This finding suggests that the activity might in fact be useful for some students in some circumstances.

Concerns regarding the oral/aural aspect of the process ranged from complaints about finding it difficult to understand the pronunciation of others to finding it difficult to comprehend fully the meaning of a long piece of text without having a written copy.

Another aspect that received mixed comments from the students was the sharing of essays. Almost all of them enjoyed listening to the essays written by others. They appreciated the opportunity to "find out how others are using different words" and "good sentences" as well as the chance to find out others' ideas and approach to a topic. Concerns regarding sharing of essays, however, were voiced by one student as follows:

I was getting confused as we discussed about our essay. Because our style of essay was different. One wrote about a kind of story that she had experienced with him whom she described. But mine is totally just a description with some example.

This student was not sure which style was correct. Some students were unhappy about their own essays when they compared them with those of others. One student stated, "I am disappointed at mine while I listen others." 
Although each of the above two aspects of the task resulted in both gains and concerns as perceived by the students, there were no negative comments articulated with regard to working with fellow students as a group. All students felt comfortable with the members of their peer groups, and they appreciated having "learned how to say someone politely that she/he need some changes in their essay or this is right and this is wrong." Students were also aware that they had to "respect group members' writing."

The benefits students perceived support the findings of previous studies, for example, increased audience awareness (Mittan, 1989; Urzua, 1987); opportunities to practice listening (Gass \& Selinker, 1994; Hedgcock \& Lefkowitz, 1992; Long \& Porter, 1985); seeing text in a new way by reading it aloud (Hedgcock \& Lefkowitz, 1992); and learning from others' writing (Villamil \& De Guerrero, 1996). However, some of the students had problems with the concept of peer feedback.

\section{Observation 3. Students had problems with the concept of peer feedback.}

It was evident from the journal entries that some students had difficulty accepting the idea of actually giving feedback to their peers. Several times in their journals students expressed a feeling of inadequacy about giving feedback. Riyoko was worried about "giving them useless feedback," while Naomi felt she did not "know how to advice properly about their essays. Their essays sound perfect." Worries about criticizing others' work pervaded the journal entries. For example, one student found it "very difficult to give right suggestions about something negative. Also it is very hard to tell the person who write the essay negative things frankly because I don't want to hurt his or her feelings." The latter quote summarizes the most common sentiments expressed by students on the issue of giving negative feedback.

The issue of peer versus teacher feedback was directly addressed by some students. They reflected on their preferences for teacher feedback, supporting the findings of previous studies that students favor teacher feedback over peer feedback or self-correction (Saito, 1994; Zhang, 1995). The following quotation is an example: "Personally, I like teacher teaches thing directly instead lead the student puzzle and find their own way." Some students described feeling irritated when "some opinions are wide of the mark, that is someone is misunderstand what I want to say in my essay." Others had concerns about the usefulness of feedback from peers.

Although student perceptions of peer response were both positive and negative, many of the students gained while participating in the sessions. In the first place, they were provided with a chance to engage in sociocognitive activities that enable students to become aware of deficiencies in their text and, in turn, to make revisions (Villamil \& De Guerrero, 1996). 
Observation 4. Students engaged in the sociocognitive activities of reading, evaluating, pointing to trouble sources, writing comments, and discussing task procedures.

Reading was the initial step in the peer response session. During the reading, several students made "self response revisions ... comments or asides" (Villamil \& De Guerrero, 1996, p. 57). For example, Sukjivan stumbled in the midst of her reading, "a powerful, a power [aside] oh no, this is not right, something's wrong." Bill too stopped and interjected indicating he was aware of a problem, stating, "There, they may not using cash [aside] what? ... Since there may not using cash after the year 2,000 [aside], oh! Ah!" Grace also interjected in the midst of her reading, "It's boring, right?" as an aside. It was possible that Grace was responding to nonverbal responses on the part of the listeners, or her comment could have been prompted by her own awareness of the uninspiring nature of the essay.

Another sociocognitive activity students experienced was evaluating. They were able to make general evaluative statements, such as "Your essay was very interesting!" and more detailed evaluative remarks such as "I like your introduction. I think the introduction grab the audience." As a result of the above, students became more aware of the trouble sources (Villamil \& De Guerrero, 1996) or areas of confusion while listening to the essays being read. According to Villamil and De Guerrero (1996), trouble sources include words that students did not understand, grammar problems, and inconsistencies in the text. One example of a trouble source that Chie expressed is illustrated in the words to Riyoko, "I'm not sure last paragraph. Did you say something about negative thing about credit card?" This was a trouble source for Chie because Riyoko was writing about the advantages of credit cards, and consequently the negative comment confused Chie.

The students also engaged in writing comments. As they listened they made notes on the good points, the ideas that did not work, the areas of confusion, and their first impressions of the text being presented.

There were also a few instances of the students discussing task procedures, for example, "Finished!" "That's enough!" and Jaesun's reference to the tape-recorder, "It bothers me actually; I can't speak." The procedural comments evident in the tapes helped keep students on-task and revealed their understanding of and commitment to the process.

It is evident that peer response groups prompted a large number of sociocognitive activities. The findings are remarkably similar to those of Villamil and De Guerrero's (1996) study. In both studies, the sessions were equally rich and complex despite the differences in student sample and research design. The present study recorded five sociocognitive activities, whereas Villamil and De Guerrero recorded seven. Because the present study chose an oral response format, the students did not compose new sentences, nor did they actually deal with trouble sources. In the present 
study the students pointed to trouble sources while the author noted them and determined whether to make changes during subsequent revision.

Observation 5. Students provided scaffolding in peer response sessions.

Ten substrategies for providing scaffolding (Villamil \& De Guerrero, 1996) were evident in varying degrees and frequency in this study: Instructing, Announcing, Justifying, Restating, Giving directives, Requesting clarification, Clarifying, Eliciting, Responding to elicitation, and Reacting. Examples follow.

Instructing occurred when Jaesun responded to Yukiko's question on the meaning of the word reputation. Jaesun's response was more than a simple definition: "Reputation means the store is very good. Price is very low and they don't cheat customers. It has good reputations. They overcharged people. They don't-we can't get a refund. That's bad reputation."

Announcing was found when Sukjivan announced, "My topic is the use of money in Canada and India." This was an organizer that focused attention so that the task could continue.

Justifying occurred only once in this study. Jaesun explained to a group member that she used the term farmer's market because "if I say just traditional market, then you don't know what it's like."

Restating was used to indicate understanding:

Terumi: I wonder how many good points you put in one paragraph

Bill: - Ah ...

Termi: $\quad$ Like...

Bill: $\quad$ I use two point in one paragraph

Terumi: Two points for one paragraph. I use two points for one paragraph.

Giving directives did not occur frequently because the structure of the sessions limited the use of this substrategy: students did not have written copies of their peers' essays. However, Sukjivan did direct George to correct a grammar error. She consulted George's essay when she could not understand if he meant "air miles" or "air mail."

Requesting clarification and clarification were evident in the conversation among Grace, Bill, and Terumi. Grace and Bill did not understand the problem Terumi faced when she tried to reserve a hotel room without a credit card. They asked questions to solicit Terumi's intended answer. In response, Terumi clarified her meaning by reminding Grace and Bill that she was not discussing reserving a hotel room in person without a credit card but reserving one in advance over the phone without a credit card as a guarantee of payment.

The substrategies eliciting and responding to elicitation were found in the conversation between Jaesun and Riyoko regarding Riyoko's essay. Jaesun 
queried, "You said credit card is the most important card. Why?" In response to Jaesun's query, Riyoko stated,

You don't think so? Just because they are used instead of money so they can use ... Credit cards instead of money so money is not most important. By important we need money, but I thought I might change this paragraph.

By the end of this statement, Riyoko was acknowledging a problem with this paragraph and at least considering change.

An important component of the task of peer response was reacting in both general and specific ways to the essay under consideration. General comments such as the following were found throughout the tapescripts, "I like your introduction and I like your essay style as a comparison between difference of Canadian and Indian. It makes more clear and easy to understand. I like your essay."

Similar to the findings of Villamil and De Guerrero's (1996) study, the students in the present study employed a number of scaffolding substrategies to help each other understand responses to essays. It is encouraging to note that a heterogeneous group of students in a classroom situation reap many of the same benefits of peer interaction as the students in a more controlled, homogeneous environment.

\section{Observation 6. Some students used feedback from peer response sessions in} revising their essays.

In the study three of the 12 participants received no suggestions from their peers, nor were they directed to trouble sources in their writing. Their revised essays owed nothing to the peer response sessions. Two other students received feedback that they did not take into account when revising their essays. However, the remaining students, seven out of 12 , made use of the peer comments to make changes in their essays.

George, Naomi, and Bill all received feedback on two aspects of their writing. Each chose to ignore one comment and use the other in the revised essay. George corrected a grammatical error pointed out to him, but he did not alter the conclusion of his essay as his fellow student suggested. Yukiko and Chie both made a number of revisions to their drafts, some of which were the result of the peer response sessions. Yukiko, for example, added a sentence after an expression that had puzzled Riyoko. Chie also used a comment when she made revisions to the thesis sentence of her essay. A comparison of the two indicated her attempt to respond to Jaesun's feedback.

Draft. By using the advertisement the consumers can spend money carefully. There are lots of different medial strategies to sell a product to consumers. 
Revised version. Occasionally, an enormous information is confused and blinded consumer's right decision. However, a wise consumer has several methods to pick up a correct information by using a media. There are main media a wise consumer does.

Although the revised version may not have been an improvement on the original, it is evidence of an attempt to respond to the needs of a wider audience as represented by peers. Another noteworthy addition as a result of Chie's participation in the peer response sessions was her appropriation of the word reputation, which was used and explained by Jaesun. Terumi and Sukjivan also used the feedback they received in their revisions. Sukjivan's revisions were the most extensive in the study. She revised all problematic areas of her writing and added idioms because the group had appreciated her natural use of these expressions. In short, seven of 12 students $(58 \%)$ made revisions based on peer response, a proportion similar to Mendonça and Johnson's (1994) finding that "in 53\% of the instances of revisions, students incorporated their peers' comments" (p. 758).

\section{Observation 7. Both less and more proficient students benefited from peer response} sessions.

Although, as stated above, students' revised essays might not have been an improvement on their first draft, the instructor noted that both less proficient and more proficient students gained from participating in peer response sessions. They gained in language awareness and self-confidence. First, she noted that the less proficient students were able to participate equally in the assigned task with other more proficient students. For example, Chie, the student who repeated the course, was able to make comments about the essays she heard. Evidently she evaluated the essays, pointed to trouble sources, and participated as an equal member of her peer response group. Second, all students learned to use proper expressions, such as "I think," "In my opinion," and so on, as well as to avoid saying "You can't," "You should," or "You are wrong." In the tapescript it was evident that the more proficient students used polite expressions such as, "I wonder," "I'm wondering." They also remembered to thank their fellow students for their comments. They seemed to have become more aware of the obligation to avoid hurting others' feelings and to help others improve their writing. The less proficient were also concerned not to hurt the feelings of others by giving negative feedback. Yet another benefit that students gained and perceived to have gained was improvement in their listening skills, discussed in Observation 2.

A final benefit experienced by most students, whatever their proficiency level, appears to be an increased self-confidence and sense of comfort when participating in peer response sessions with classmates. Sukjivan remarked that even though the composition of the groups changed at mid-term, the 
comfortable atmosphere continued. When Yukiko began the peer response sessions, she was embarrassed and nervous about reading her essay aloud, but by the end of the semester she was enthusiastic about the process.

\section{The Instructor's Advice}

In view of the positive results of the study, the instructor advises teachers to use peer response groups in their writing classrooms because the benefits are considerable for ESL students. Although conducting peer response is not without problems, the time and effort required for mitigating difficulties are worth expending. Experience reveals that students should be given intensive training to enable them to participate fully in the process, and that they need to be taught appropriate language. Earlier research shows that politeness strategies and facilitative language enhance the cooperative atmosphere in the sessions and result in greater social and academic benefits (Mangelsdorf \& Schlumberger, 1992; Nelson \& Murphy, 1993). The present research indicates that ESL students are able to use politeness strategies when they have been taught to do so. The instructor also feels that students will benefit from practice sessions in the use of scaffolding substrategies, perhaps as a wholeclass activity with a model essay, prior to the peer response sessions.

To ensure success, the teacher could bring the advantages inherent in peer response sessions to the awareness of the students by explicitly presenting all the benefits of peer response sessions in class. When conducting the sessions, it is also advisable for the teacher to vary some of the components of the sessions from time to time, for example, by changing the group size from foursomes to dyads and, perhaps at times allowing students to have written copies of the essays. Some ESL students may understand the presentation more fully and give more detailed comments with a written text in front of them.

Finally, the teacher could impress on students that peer response is but one of several sources of feedback. Students may be even more receptive to peer response sessions if they know that peer feedback is not the only form of feedback they receive in writing classes, but that teacher feedback is available as well.

\section{The Authors}

Gloria M. Tang is an associate professor in the Department of Language Education at the University of British Columbia, Vancouver, BC.

Joan Tithecott, an experienced ESL instructor, is a lecturer at the University College of the Cariboo, Kamloops, BC.

\section{References}

Cazden, C. (1988). Classroom discourse: The language of teaching and learning. Portsmouth, $\mathrm{NH}$ : Heinemann. 
Coelho, E. (1992). Cooperative learning: Foundation for a communicative curriculum. In C. Kessler (Ed.), Cooperative language learning: A teacher's resource book (pp. 31-50). Englewood Cliffs, NJ: Prentice Hall Regents.

Connor, U., \& Asenavage, K. (1994). Peer response groups in ESL writing classes: How much impact on revision? Journal of Second Language Writing, 3, 257-276.

DiPardo, A., \& Freedman, S. (1988). Peer response groups in the writing classroom: Theoretic foundations and new directions. Review of Educational Research, 58(2), 119-149.

Elbow, P. (1973). Writing without teachers. London: Oxford University Press.

Fathman, A., \& Whalley, E. (1990). Teacher response to student writings: Focus on form versus content. In B. Kroll (Ed.), Second language writing: Research insights for the classroom (pp. 178-190). New York: Cambridge University Press.

Flavell, J. (1979). Metacognition and cognitive monitoring: A new area of cognitivedevelopmental inquiry. American Psychologist, 34, 906-911.

Flower, L., \& Hayes, J. (1981). A cognitive process theory of writing. College Composition and Communication, 32(4), 365-387.

Gass, S., \& Selinker, L. (1994). Second language acquisition. Hillsdale, NJ: Erlbaum.

Gregg, J. (1993). Communication and culture (4th ed.). Boston, MA: Heinle \& Heinle.

Hedgcock, J., \& Lefkowitz, N. (1992). Collaborative oral/aural revision in foreign language writing instruction. Journal of Second Language Writing, 1(3), 255-276.

Hilgers, T. (1986). How children change as critical evaluators of writing: Four three-year case studies. Research in the Teaching of English, 20(1), 36-55.

Krashen, S. (1982). Principles and practice in second language acquisition. London: Pergamon.

Leech, G., \& Svartvik, J. (1975). A communicative grammar of English. Singapore: Longman.

Long, M., \& Porter, P. (1985). Group work, interlanguage talk and second language acquisition. TESOL Quarterly, 19, 207-227.

Mangelsdorf, K. (1989). Parallels between speaking and writing in second language acquisition. In D. Johnson \& D. Roen (Eds.), Richness in writing: Empowering ESL students (pp. 134-135). White Plains, NY: Longman.

Mangelsdorf, K. (1992). Peer reviews in the ESL composition classroom: What do the students think? ELT Journal, 46, 274-284.

Mangelsdorf, K., \& Schlumberger, A. (1992). ESL student response stances in peer review task. journal of Second Language Writing, 3, 235-254.

McGroarty, M. (1989). The benefits of cooperative learning arrangements in second language instruction. NABE Journal, Winter, 127-143.

Mendonça, C., \& Johnson, K. (1994). Peer review negotiations: Revision activities in ESL writing instruction. TESOL Quarterly, 28, 745-769.

Mittan, R. (1989). The peer review process: Harnessing students' communicative power. In D. Johnson \& D. Roen (Eds.), Richness in writing: Entpowering ESL students (pp. 207-219). White Plains, NY: Longman.

Nelson, G., \& Murphy, J. (1993). Peer response groups: Do L2 writers use peer comments in revising their drafts? TESOL Quarterly, 27, 135-141.

Obah, T. (1993). Learning from others in the ESL writing class. English Quarterly, 25(1), 8-13.

Olsen R., \& Kagan, S. (1992). About cooperative learning. In C. Kessler (Ed.), Cooperative language learning: A teacher's resource book (pp. 1-30). Englewood Cliffs, NJ: Prentice Hall Regents.

Saito, H. (1994). Teachers' practices and students' preferences for feedback on second language writing: A case study of adult ESL learners. TESL Canada Journal, 11(2), 46-70.

Samway, K. (1993). "This is hard isn't it?": Children evaluating writing. TESOL Quarterly, 27, 233-257.

Savignon, S. (1991). Communicative language teaching: State of the art. TESOL Quarterly, 25, 261-277. 
Silva, T. (1990). Second language composition instruction: Developments issues and directions. In B. Kroll (Ed.), Second language writing (pp. 11-23). New York: Cambridge University Press.

Slavin, R. (1991). Synthesis of research on cooperative learning. Educational Leadership, 48, 71-82.

Student writing groups: Demonstrating the process. (1988). Video and teachers' guide. Tacoma, WA: Workshop Productions.

Swain, M. (1985). Communicative competence: Some roles of comprehensible input and comprehensible output in its development. In S. Gass \& C. Madden (Eds.), Input in second language acquisition (pp. 235-253). Rowley, MA: Newbury House.

Tithecott, E.J. (1997). Peer response and second language writers. Unpublished master's thesis, University of British Columbia.

Urzua, C. (1987). "You stopped too soon": Second language children composing and revising. TESOL Quarterly, 21, 279-299.

Villamil, O., \& De Guerrero, M. (1996). Peer revision in the second language classroom: Social cognitive activities, mediating strategies and aspects of social behavior. Journal of Second Language Writing, 3(1), 51-75.

Vygotsky, L. (1986). Thought and language (2nd ed.). Cambridge, MA: MIT Press.

Zamel, V. (1983). The composing processes of advanced ESL students: Six case studies. TESOL Quarterly, 17, 165.

Zhang, S. (1995). Reexamining the affective advantage of peer feedback in the ESL writing class. Journal of Second Language Writing, 4(3), 209-222. 